\title{
Perengkingan Pengetahuan Dalam Time Series Data Mining dengan J-Measure
}

\author{
Relita Buaton', Muhammad Zarlis ${ }^{2}$, Herman Mawengkang², Syahril Efendi ${ }^{2}$ \\ ${ }^{1}$ Graduate Program Of Computer Science, \\ ${ }^{2}$ Department Of Computer Science \\ Faculty of Compurer Science and Information technology, \\ Universitas Sumatera Utara, Medan, Indonesia \\ bbcbuaton@gmail.com
}

\begin{abstract}
Computer system development is increasing very rapidly in generating and collecting data that can be seen in terms of the application of computerized systems that continuously improve transaction data in the business world and in government systems, as well as the ability of hardware to store data with large capacity, increasing interest in mining data in accordance with technological developments, including problems related to computer science and data representation which are considered effective and efficient solutions. In this study the technique used is processing time series data, some of the knowledge produced is then ranked so that priority knowledge is obtained with a high level of confidence. Proximity distance using j-measure euclidean and cracking. Based on the results of cracking found rules based on the level of confidence that can be used as a decision support
\end{abstract}

Keywords: data mining time series cracking, j-measure

Abstrak- Pengembangan sistem komputer meningkat sangat cepat dalam menghasilkan dan mengumpulkan data yang dapat dilihat dari sisi penerapan sistem komputerisasi yang terus meningkatkan data transaksi di dunia bisnis dan dalam sistem pemerintahan, serta kemampuan perangkat keras untuk menyimpan data dengan kapasitas besar, terjadi peningkatan minat dalam menambang/menggali data sesuai dengan perkembangan teknologi, diantaranya adalah permasalahan yang berkaitan dengan ilmu komputer dan representasi data yang dianggap sebagai solusi yang efektif dan efisien. Dalam penelitian ini teknik yang digunakan adalah melakukan pengolahan data time series, beberapa pengetahuan yang dihasilkan kemudian dirangking sehingga diperoleh pengetahuan prioritas dengan tingkat keyakinan yang tinggi. Jarak kedekatan dengan menggunakan euclidean dan perengkingan j-measure. Berdasarkan hasil perengkingan ditemukan aturan berdasarkan tingkat keyakinan yang dapat digunakan sebagai pendukung keputusan

Kata kunci:perengkingan time series data mining, j-measure

\section{PENDAHULUAN}

\subsection{Time Series Data Mining}

Dalam kurun waktu beberapa tahun belakangan ini, telah terjadi peningkatan minat dalam menambang/menggali data sesuai dengan perkembangan teknologi, diantaranya adalah permasalahan yang berkaitan dengan ilmu komputer dan representasi data yang dianggap sebagai solusi yang efektif dan efisien. Dalam penambangan data berkala (time series data mining), masalah mendasar adalah bagaimana menyajikan data berkala. Salah satu pendekatan yang umum adalah mengubah deret berkala menjadi domain lain sehingga dimensi dikurangi yang diikuti oleh mekanisme indeks, penelitian deret waktu tidak optimal karena masih terbatas pada data penambangan yang belum 
dapat mewakili deret waktu [1], dapat menemukan pola dalam data deret waktu [2], pola ini perlu dikembangkan untuk mengubah pola menjadi aturan. Aturan dapat ditemukan dari data deret waktu, tetapi masih dibatasi oleh overfitting [3]. Selanjutnya, ukuran kesamaan dalam urutan periodik atau sub urutannya dan proses segmentasi adalah dua tugas utama untuk berbagai tugas yang termasuk dalam penambangan periodik. Salah satu tugas penambangan adalah aturan penemuan (rule discovery). Serangkaian berkala dapat dikonversi menjadi representasi diskrit dengan terlebih dahulu membentuk sub-urutan dan kemudian mengelompokkan sub urutan ini menggunakan ukuran yang sesuai dari pola kesamaan. Pengembangan sistem komputer meningkat sangat cepat dalam menghasilkan dan mengumpulkan data yang dapat dilihat dari sisi penerapan sistem komputerisasi yang terus meningkatkan data transaksi di dunia bisnis dan dalam sistem pemerintahan, serta kemampuan perangkat keras untuk menyimpan data dengan kapasitas besar. Kumpulan basis data yang dihasilkan dari berbagai sumber dalam manajemen bisnis dan administrasi pemerintahan serta penerapan berbagai aplikasi lainnya. Dengan perkembangan ukuran basis data yang sangat cepat itu dapat mempengaruhi kinerja dan kemampuan sistem basis data. Ini menciptakan teknik baru dalam mengelola kumpulan atau tumpukan data dari data transaksi basis data besar untuk mengekstrak informasi berharga dari basis data yang sebelumnya tidak dikenal. Oleh karena itu penambangan data sangat penting untuk menjadi objek dan studi penelitian saat ini[4]

\subsection{Cluster Analisis}

Analisis cluster adalah proses mempartisi set data atau observasi menjadi beberapa bagian. Setiap subset adalah sebuah cluster, jadi objek yang berada dalam satu cluster mirip satu sama lain, tetapi berbeda dari objek dalam kelompok lain. Cluster cluster yang dihasilkan dari analisis cluster dapat disebut sebagai clustering, metode pengelompokan yang berbeda dapat menghasilkan pengelompokan yang berbeda dalam kumpulan data yang sama. Sistem partisi dilakukan dengan algoritma clustering. Oleh karena itu, pengelompokan bermanfaat karena dapat menghasilkan penemuan kelompok yang sebelumnya tidak dikenal dalam data. Analisis Cluster telah banyak digunakan dalam banyak aplikasi seperti intelijen bisnis, pengenalan pola gambar, pencarian web, biologi, dan keamanan. Dalam intelijen bisnis, pengelompokan dapat digunakan untuk mengatur sejumlah besar pelanggan ke dalam kelompok, dimana pelanggan dalam kelompok memiliki karakteristik yang sama. Untuk menemukan cluster dalam grafik yaitu dengan memotong grafik menjadi beberapa bagian, setiap bagian menjadi sebuah cluster, secara formal untuk grafik $G=(V, E)$, untuk memotong $C=$ $(\mathrm{S}, \mathrm{T})$, yang merupakan partisi dari vertex set $\mathrm{V}$ di $\mathrm{G}$. $\mathrm{V}=\mathrm{SUT}$ dan $\mathrm{S} \cap \mathrm{T}=\theta$. Bagian yang dimaksudkan untuk menghasilkan cluster adalah menggunakan potongan minimum sesuai dengan teori grafik. Sepotong dikatakan minimum jika ukuran potongan tidak lebih besar dari ukuran potongan lainnya [1]. 


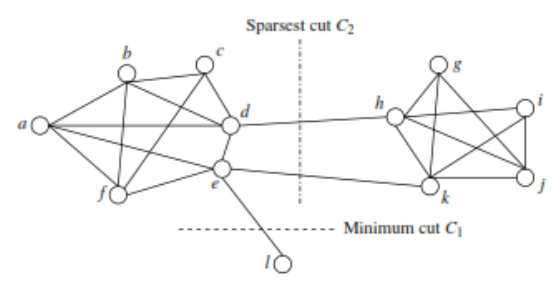

Gambar 1. Grafik dengan 2 buah cluster

Menurut [5], memberikan perspektif inovatif dan memberikan solusi optimal menggunakan algoritma yang dapat menemukan motif atau pola deret waktu melalui kumpulan partikel. Dengan mempertimbangkan data dari berbagai domain, penggunaan kumpulan partikel adalah solusi kompetitif dibandingkan dengan studi sebelumnya karena dapat menemukan motif yang sebanding dalam waktu singkat dan memori minimal. Time Series adalah urutan bilangan real yang diukur secara berurutan, biasanya dalam bentuk interval waktu reguler. Data dalam bentuk deret waktu mencakup data dari ekonomi ke kedokteran, dari biologi ke fisika, dan dari ilmu sosial ke komputer. Pengulangan data merupakan karakteristik mendasar dari sistem alami dan buatan seperti pengukuran aktivitas sistem, deret waktu yang menjadi pasangan segmen data. Pasangan segmen ini biasanya disebut motif [6] dan keberadaan mereka tidak mungkin terjadi secara kebetulan. Bahkan, mereka biasanya membawa informasi penting tentang sistem.

Untuk mengevaluasi kualitas clustering dengan menggunakan cross entropy yang dinyatakan sebagai berikut

a. $\quad$ Cross entropy $=\sum_{j=1}^{k}\left(\frac{n_{j}}{|S D B|}\right)\left(-\sum_{i=1}^{m} P_{i j} \log \left(p_{i j}\right)\right)$

$\mathrm{K}=\mathrm{jumlah}$ cluster

$n_{j}=$ jumlah sequence dalam $\mathrm{j}$ cluster

$m=$ jumlah class dalam sequence database

$p_{i j}=$ probabilitas secara random $\mathrm{j}$ cluster

$S D B=$ sequence database

a. J-Measure

Digunakan untuk perengkingan rule, yang didefenisikan sebagai berikut

$J\left(B_{T} ; A\right)=p(A) *\left(p\left(B_{T} \mid A\right) \log \left(\frac{p\left(B_{T} A\right)}{P\left(B_{T}\right)}\right)+\left(1-p\left(B_{T} \mid A\right)\right) \log \left(\frac{1-p\left(B_{T} \mid A\right)}{1-p\left(B_{T}\right)}\right)\right)$

$\mathrm{p}(\mathrm{A})$ adalah probabilitas simbol A yang berada dalam lokasi acak secara berurutan

$p\left(B_{T}\right)$ adalah probabilitas dari paling sedikit satu B terjadi dalam sebuah pilihan acak selama durasi $\mathrm{t}$

$p\left(B_{T} \mid A\right)$ adalah probabilitas dari paling sedikit satu $B$ terjadi dalam sebuah pilihan acak selama durasi $T$ yang diberikan oleh proses A. [7]

\subsection{Penelitian Terkait}

Masalah segmentasi dapat disajikan dalam beberapa cara yakni

a. Diberikan Time series $\mathrm{T}$, menghasilkan representasi terbaik hanya dengan menggunakan K segmen.

b. Diberikan Time series $\mathrm{T}$, menghasilkan representasi terbaik sehingga maksimum kesalahan yang terjadi pada segmen apa pun tidak melebihi ambang batas yang ditentukan pengguna 
c. Diberikan Time series T, menghasilkan representasi terbaik sehingga kesalahan gabungan semua segmen kurang dari ambang batas yang ditentukan pengguna dari total kesalahan maks.

Berikutnya akan dijelaskan bahwa tidak semua algoritma mendukung semua spesifikasi tersebut. Algoritma segmentasi juga dapat diklasifikasikan sebagai batch atau online. Penelitian dalam data mining sangat diperlukan untuk menghasilkan peramalan linear dengan berbagai algoritma dan literatur terkait seperti dalam bidang kartografi atau grafik komputer. Dalam hal ini, akan ditinjau tiga pendekatan segmentasi utama dalam literatur dan memberikan evaluasi empiris yang luas dengan kumpulan data yang sangat heterogen dari keuangan, kedokteran, manufaktur dan sains. Hasil utama dari eksperimen ini adalah bahwa algoritma online dalam literatur menghasilkan perkiraan data yang sangat buruk, dan bahwa satu-satunya algoritma yang secara konsisten menghasilkan hasil dan kualitas tinggi. Hasil ini memberikan rekomendasi untuk memperkenalkan algoritma online baru yang berskala linier dalam ukuran kumpulan data, online, dan menghasilkan perkiraan kualitas tinggi. Tiga pendekatan utama dalam segmentasi time series, sebagian besar dapat dikelompokkan dalam kategori berikut:

1. Sliding Windows: Segmen ditanam hingga melebihi batas kesalahan. Proses ini berulang dengan titik data berikutnya dan segmen yang baru tidak termasuk dalam data baru pada segmen yang diperkirakan.

2. Top-Down: Time series dipecah secara rekursif sampai berhenti dan kriteria terpenuhi.

3. Bottom-Up: Dimulai dari perkiraan yang paling mungkin, segmen digabung hingga beberapa kriteria dipenuhi.[8][9]

\section{METODE PENELITIAN}

Untuk menghasilkan keputusan dari sejumlah aturan yang dihasilkan, maka secara umum tahapan dan kerangka kerja penelitian yang digunakan adalah dengan mengembangkan kerangka penelitian yang telah dikembangkan digambarkan pada diagram blok sebagai berikut:

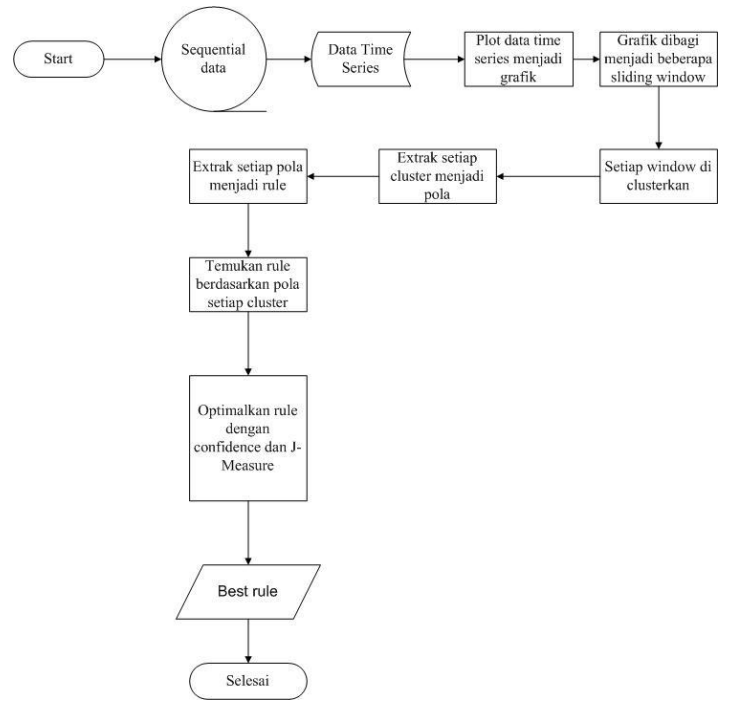

Gambar 2. Kerangka Kerja Penelitian 
Data yang digunakan sebagai pengujian yakni data suhu rata-rata hasil pengukuran temperatur suhu

Tabel 1. Data Time Series Temperatur

\begin{tabular}{|c|c|c|c|c|c|c|c|}
\hline Tahun & Suhu $\left({ }^{\circ} \mathrm{C}\right)$ & Tahun & Suhu $\left({ }^{\circ} \mathrm{C}\right)$ & Tahun & Suhu $\left({ }^{\circ} \mathrm{C}\right)$ & Tahun & Suhu $\left({ }^{\circ} \mathrm{C}\right)$ \\
\hline 1782 & 15,58 & 1885 & 14,57 & 1833 & 14,68 & 1936 & 14,8 \\
\hline 1783 & 15,96 & 1886 & 15,06 & 1834 & 17,41 & 1937 & 15,84 \\
\hline 1784 & 16,18 & 1887 & 14,72 & 1835 & 15,29 & 1938 & 14,93 \\
\hline 1785 & 14,43 & 1888 & 14,5 & 1836 & 14,66 & 1939 & 14,54 \\
\hline 1786 & 13,78 & 1889 & 15,13 & 1837 & 14,59 & 1940 & 14,51 \\
\hline 1787 & 14,66 & 1890 & 14,3 & 1838 & 14,32 & 1941 & 14,1 \\
\hline 1788 & 16,53 & 1891 & 14,72 & 1839 & 14,82 & 1942 & 15,68 \\
\hline 1789 & 15,25 & 1892 & 15,37 & 1840 & 14,68 & 1943 & 15,72 \\
\hline 1790 & 15,35 & 1893 & 15,13 & 1841 & 15,41 & 1944 & 15,18 \\
\hline 1791 & 15,75 & 1894 & 14,23 & 1842 & 15,56 & 1945 & 15,45 \\
\hline 1792 & 14,96 & 1895 & 15,46 & 1843 & 13,58 & 1946 & 15,76 \\
\hline 1793 & 15,72 & 1896 & 13,89 & 1844 & 14,07 & 1947 & 17,49 \\
\hline 1794 & 16,27 & 1897 & 14,52 & 1845 & 14,21 & 1948 & 14,94 \\
\hline 1795 & 15,56 & 1898 & 14,83 & 1846 & 17,23 & 1949 & 15,54 \\
\hline 1796 & 15,9 & 1899 & 15,01 & 1847 & 16,44 & 1950 & 16,9 \\
\hline 1797 & 16,58 & 1900 & 15,47 & 1848 & 15,55 & 1951 & 15,44 \\
\hline 1798 & 16,09 & 1901 & 15,52 & 1849 & 15,12 & 1952 & 15,79 \\
\hline 1799 & 14,88 & 1902 & 13,93 & 1850 & 14,37 & 1953 & 15,38 \\
\hline 1800 & 15,97 & 1903 & 14,91 & 1851 & 13,44 & 1954 & 14,36 \\
\hline 1801 & 16,02 & 1904 & 15,76 & 1852 & 15,42 & 1955 & 14,46 \\
\hline 1802 & 15,55 & 1905 & 15,52 & 1853 & 15,16 & 1956 & 14,43 \\
\hline 1803 & 14,84 & 1906 & 14,36 & 1854 & 14,81 & 1957 & 14,18 \\
\hline 1804 & 15,99 & 1907 & 14,8 & 1855 & 14,88 & 1958 & 16,01 \\
\hline 1805 & 14,29 & 1908 & 14,74 & 1856 & 14,93 & 1959 & 15,58 \\
\hline 1806 & 15,72 & 1909 & 13,54 & 1857 & 15,74 & 1960 & 14,77 \\
\hline 1807 & 17,43 & 1910 & 13,76 & 1858 & 15,14 & 1961 & 15,36 \\
\hline 1808 & 16,94 & 1911 & 16,27 & 1859 & 16,39 & 1962 & 14,73 \\
\hline 1809 & 15,73 & 1912 & 13,3 & 1860 & 14,46 & 1963 & 15,47 \\
\hline 1810 & 15,87 & 1913 & 13,4 & 1861 & 15,4 & 1964 & 16,24 \\
\hline 1811 & 17,21 & 1914 & 14,08 & 1862 & 15,5 & 1965 & 14,13 \\
\hline 1812 & 15,43 & 1915 & 15,06 & 1863 & 15,45 & 1966 & 14,84 \\
\hline 1813 & 14,1 & 1916 & 13,93 & 1864 & 14,1 & 1967 & 15,58 \\
\hline 1814 & 13,72 & 1917 & 16,78 & 1865 & 16,3 & 1968 & 14,63 \\
\hline 1815 & 14,65 & 1918 & 14,56 & 1866 & 15,09 & 1969 & 15,1 \\
\hline 1816 & 13,34 & 1919 & 14,65 & 1867 & 14,72 & 1970 & 15,02 \\
\hline 1817 & 15,04 & 1920 & 15 & 1868 & 16,62 & 1971 & 15,16 \\
\hline 1818 & 14,93 & 1921 & 16,16 & 1869 & 14,87 & 1972 & 14 \\
\hline 1819 & 15,68 & 1922 & 14,62 & 1870 & 14,72 & 1973 & 15,68 \\
\hline 1820 & 14,5 & 1923 & 14,99 & 1871 & 14,44 & 1974 & 14,5 \\
\hline 1821 & 14,13 & 1924 & 14,62 & 1872 & 15,22 & 1975 & 15,4 \\
\hline 1822 & 16,17 & 1925 & 14,59 & 1873 & 15,14 & 1976 & 15,12 \\
\hline 1823 & 15,22 & 1926 & 14,3 & 1874 & 15,14 & 1977 & 14,54 \\
\hline 1824 & 14,71 & 1927 & 15,15 & 1875 & 15,91 & 1978 & 13,94 \\
\hline 1825 & 15,16 & 1928 & 15,13 & 1876 & 14,71 & 1979 & 14,78 \\
\hline 1826 & 15,65 & 1929 & 15,87 & 1877 & 14,46 & 1980 & 14,28 \\
\hline 1827 & 15,71 & 1930 & 15,31 & 1878 & 14,71 & 1981 & 15,04 \\
\hline 1828 & 14,98 & 1931 & 14,78 & 1879 & 14,13 & 1982 & 16,06 \\
\hline 1829 & 14,15 & 1932 & 15,94 & 1880 & 14,24 & 1983 & 15,94 \\
\hline 1830 & 15,12 & 1933 & 14,42 & 1881 & 14,78 & 1984 & 13,91 \\
\hline
\end{tabular}




\begin{tabular}{|l|l|l|l|l|l|l|l|}
\hline Tahun & Suhu $\left({ }^{\mathbf{}} \mathbf{C}\right)$ & Tahun & Suhu $\left({ }^{\mathbf{}} \mathbf{C}\right)$ & Tahun & Suhu $\left({ }^{\mathbf{0}} \mathbf{C}\right)$ & Tahun & Suhu $\left({ }^{\mathbf{C}} \mathbf{C}\right)$ \\
\hline 1831 & 14,64 & 1934 & 15,83 & 1882 & 13,53 & 1985 & 15,36 \\
\hline 1832 & 14,51 & 1935 & 15,55 & 1883 & 14,53 & 1986 & 15,34 \\
\hline 1884 & 14,48 & 1987 & 14,67 & 1988 & 15,88 & & \\
\hline
\end{tabular}

\section{HASIL DAN PEMBAHASAN}

Langkah awal berikutnya membagi grafik menjadi beberapa window yang disebut dengan sub sequence time series, grafik dibagi menjadi beberapa window, dalam kasus ini dibagi dalam 10 window dan selanjutnya window tersebut akan menjadi pusat analisis

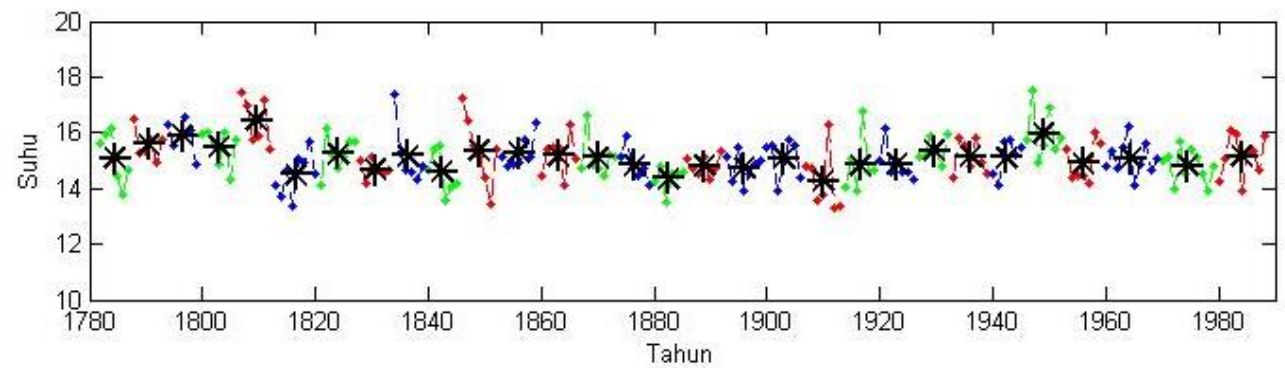

Gambar 3. Hasil Analisis Window

Gambar 3 menunjukkan hasil analisis untuk setiap window, dari $s$ dibentuk semua window (subsikuen) $s_{1}, \ldots, s_{n-w+1}$ dengan lebar $w$ dimana $s_{i}=\left(x_{i}, \ldots, x_{i+w-1}\right), s$ terdiri dari 10 window dengan lebar $w=20$ tahun, dengan menggunakan jarak euclid $d(\widehat{x}, \hat{y})=\left(\sum_{i}\left(x_{i}-y_{i}\right)^{2}\right)^{1 / 2}$ setiap window menghasilkan titik-titik yang diperoleh melalui perhitungan jarak similarity, titik tersebut merupakan hasil similarity terhadap perubahan suhu untuk setiap window seiring dengan terjadinya perubahan waktu. Setiap window menghasilkan 3 titik pusat similarity, informasi masing-masing analisis window disajikan pada tabel 2

Tabel 2. Pola yang ditemukan pada setiap analisis window periode tahunan

\begin{tabular}{|c|c|c|c|c|c|}
\hline \multirow[b]{2}{*}{ Window } & \multirow[b]{2}{*}{ Tahun } & \multirow[b]{2}{*}{ Similarity } & \multicolumn{3}{|c|}{ Pola Yang Ditemukan } \\
\hline & & & Trend Suhu & $\begin{array}{c}\text { Perubahan } \\
\text { Suhu }\end{array}$ & Waktu(Tahun) \\
\hline \multirow[t]{3}{*}{ I } & \multirow{3}{*}{$\begin{array}{l}1780- \\
1800\end{array}$} & $1784-15,1^{\circ} \mathrm{C}$ & \multirow{3}{*}{$\begin{array}{l}\text { Suhu cenderung } \\
15,1{ }^{\circ} \mathrm{C} \text { sampai } \\
\text { dengan } 15,9^{\circ} \mathrm{C}\end{array}$} & Start & \\
\hline & & $1790-15,6^{\circ} \mathrm{C}$ & & Meningkat & 6 \\
\hline & & $1796-15,9^{\circ} \mathrm{C}$ & & Meningkat & 6 \\
\hline \multirow[t]{3}{*}{ II } & \multirow{3}{*}{$\begin{array}{l}1801- \\
1820\end{array}$} & $1803-15,5^{\circ} \mathrm{C}$ & \multirow{3}{*}{$\begin{array}{l}\text { Suhu cenderung } \\
14,5{ }^{\circ} \mathrm{C} \text { sampai } \\
\text { dengan } 16,4^{\circ} \mathrm{C}\end{array}$} & Menurun & 7 \\
\hline & & $1809-16,4^{\circ} \mathrm{C}$ & & Meningkat & 6 \\
\hline & & $1816-14,5^{\circ} \mathrm{C}$ & & Menurun & 7 \\
\hline \multirow[t]{3}{*}{ III } & \multirow{3}{*}{$\begin{array}{l}1821- \\
1840\end{array}$} & $1824-15,3^{\circ} \mathrm{C}$ & \multirow{3}{*}{$\begin{array}{l}\text { Suhu cenderung } \\
14,7{ }^{\circ} \mathrm{C} \text { sampai } \\
\text { dengan } 15,3^{\circ} \mathrm{C}\end{array}$} & Meningkat & 8 \\
\hline & & $1830-14,7^{\circ} \mathrm{C}$ & & Menurun & 6 \\
\hline & & $1836-15,2^{\circ} \mathrm{C}$ & & Meningkat & 6 \\
\hline \multirow[t]{3}{*}{ IV } & \multirow{3}{*}{$\begin{array}{l}1841- \\
1860\end{array}$} & $1842-14,6^{\circ} \mathrm{C}$ & \multirow{3}{*}{$\begin{array}{l}\text { Suhu cenderung } \\
14,6{ }^{\circ} \mathrm{C} \text { sampai } \\
\text { dengan } 15,4^{\circ} \mathrm{C}\end{array}$} & Menurun & 6 \\
\hline & & $1849-15,4^{\circ} \mathrm{C}$ & & Meningkat & 7 \\
\hline & & $1856-15,3^{\circ} \mathrm{C}$ & & Menurun & 7 \\
\hline \multirow[t]{3}{*}{ V } & \multirow{3}{*}{$\begin{array}{l}1861- \\
1880\end{array}$} & $1863-15,2^{\circ} \mathrm{C}$ & \multirow{3}{*}{$\begin{array}{l}\text { Suhu cenderung } \\
14,8{ }^{\circ} \mathrm{C} \text { sampai } \\
\text { dengan } 15,2^{\circ} \mathrm{C}\end{array}$} & Menurun & 7 \\
\hline & & $1870-15,1^{\circ} \mathrm{C}$ & & Menurun & 7 \\
\hline & & $1876-14,8^{\circ} \mathrm{C}$ & & Menurun & 6 \\
\hline
\end{tabular}




\begin{tabular}{|c|c|c|c|c|c|}
\hline \multirow[b]{2}{*}{ Window } & \multirow[b]{2}{*}{ Tahun } & \multirow[b]{2}{*}{ Similarity } & \multicolumn{3}{|c|}{ Pola Yang Ditemukan } \\
\hline & & & Trend Suhu & $\begin{array}{c}\text { Perubahan } \\
\text { Suhu }\end{array}$ & Waktu(Tahun) \\
\hline \multirow[t]{3}{*}{ VI } & \multirow{3}{*}{$\begin{array}{l}1881- \\
1900\end{array}$} & $1882-14,4^{\circ} \mathrm{C}$ & \multirow{3}{*}{$\begin{array}{l}\text { Suhu cenderung } \\
14,4{ }^{\circ} \mathrm{C} \text { sampai } \\
\text { dengan } 14,8^{\circ} \mathrm{C}\end{array}$} & Menurun & 6 \\
\hline & & $1889-14,8^{\circ} \mathrm{C}$ & & Meningkat & 7 \\
\hline & & $1896-14,7^{\circ} \mathrm{C}$ & & Menurun & 7 \\
\hline \multirow[t]{3}{*}{ VII } & \multirow{3}{*}{$\begin{array}{l}\text { 1901- } \\
1920\end{array}$} & $1903-15,1^{\circ} \mathrm{C}$ & \multirow{3}{*}{$\begin{array}{l}\text { Suhu cenderung } \\
14,3{ }^{\circ} \mathrm{C} \text { sampai } \\
\text { dengan } 15,1^{\circ} \mathrm{C}\end{array}$} & Meningkat & 7 \\
\hline & & $1910-14,3^{\circ} \mathrm{C}$ & & Menurun & 7 \\
\hline & & $1916-14,8^{\circ} \mathrm{C}$ & & Meningkat & 6 \\
\hline \multirow[t]{3}{*}{ VIII } & \multirow{3}{*}{$\begin{array}{l}1921- \\
1940\end{array}$} & $1923-14,9^{\circ} \mathrm{C}$ & \multirow{3}{*}{$\begin{array}{l}\text { Suhu cenderung } \\
14,9{ }^{\circ} \mathrm{C} \text { sampai } \\
\text { dengan } 15,4^{\circ} \mathrm{C}\end{array}$} & Meningkat & 7 \\
\hline & & $1929-15,4^{\circ} \mathrm{C}$ & & Menurun & 6 \\
\hline & & $1936-15,1^{\circ} \mathrm{C}$ & & Menurun & 7 \\
\hline \multirow[t]{3}{*}{ IX } & \multirow{3}{*}{$\begin{array}{l}1941- \\
1960\end{array}$} & $1942-15,1^{\circ} \mathrm{C}$ & \multirow{3}{*}{$\begin{array}{l}\text { Suhu cenderung } \\
115,1{ }^{\circ} \mathrm{C} \text { sampai } \\
\text { dengan } 16,0^{\circ} \mathrm{C}\end{array}$} & Normal & 6 \\
\hline & & $1949-16,0^{\circ} \mathrm{C}$ & & Meningkat & 7 \\
\hline & & $1956-15,1^{\circ} \mathrm{C}$ & & Menurun & 7 \\
\hline \multirow[t]{3}{*}{$\mathrm{X}$} & \multirow{3}{*}{$\begin{array}{l}1961- \\
1980\end{array}$} & $1964-15,1^{\circ} \mathrm{C}$ & \multirow{3}{*}{$\begin{array}{l}\text { Suhu cenderung } \\
14,8{ }^{\circ} \mathrm{C} \text { sampai } \\
\text { dengan } 15,2^{\circ} \mathrm{C}\end{array}$} & Normal & 8 \\
\hline & & $1974-14,8^{\circ} \mathrm{C}$ & & Menurun & 10 \\
\hline & & $1984-15,2^{\circ} \mathrm{C}$ & & Meningkat & 10 \\
\hline
\end{tabular}

Tabel 2 memuat informasi tentang pola yang dihasilkan berdasarkan analisa grafik pada gambar 3. Jumlah baris pada kolom window sesuai dengan jumlah sequen, serta kolom tahun berdasarkan lebar interval window yang telah ditetapkan. Masing-masing window memiliki 3 interval tahun yang dihasilkan dari perhitungan jarak similarity dan setiap interval tahun memiliki data peningkatan atau penurunan suhu rata-rata, data ini diperoleh dari titik-titik similarity pada gambar 3. Perubahan pola terjadi seiring dengan perubahan waktu dalam satuan tahun yang ditunjukkan pada kolom waktu. Terjadi peningkatan dan penurunan suhu rata-rata setiap window, informasi ini termasuk hal yang menarik untuk dijadikan rule/aturan dalam pengambilan keputusan atau prediksi dimasa yang akan datang. Berdasarkan tabel 2 dihasilkan 28 rule/aturan, setiap window memiliki rule, format aturan yang digunakan adalah format dengan menggunakan logika proposisi yakni Jika A terjadi, maka B terjadi dalam waktu T tahun. Disini A dan B merupakan bentuk dasar, yaitu titik-titik similarity yang dihasilkan oleh diskritisasi pada tabel 3. Dengan menggunakan notasi matematika pada persamaan 4 dihasilkan 28 rule. Rule tersebut kemudian dicari korelasi kuat dan cenderung dengan menghitung tingkat keyakinan sehingga diperoleh rule sebagai berikut

Tabel 3. Rule dengan tingkat confidence berdasarkan pola yang ditemukan

\begin{tabular}{|c|c|c|}
\hline No & Rule & Confidence \\
\hline 1 & $\begin{array}{l}\text { IF Suhu Meningkat THEN akan Menurun dalam } 6 \text { sampai dengan } 7 \text { tahun } \\
\text { sebesar } 14,5 \text { sdampai dengan } 15,5^{\circ} \mathrm{C}\end{array}$ & $\begin{array}{l}=\frac{9}{12} \times 100 \% \\
=75 \%\end{array}$ \\
\hline 2 & $\begin{array}{l}\text { IF Suhu Menurun THEN akan Meningkat dalam } 6 \text { sampai dengan } 10 \text { tahun } \\
\text { sebesar } 14,8 \text { sdampai dengan } 16,4^{\circ} \mathrm{C}\end{array}$ & $\begin{array}{l}=\frac{8}{15} \times 100 \% \\
=53 \%\end{array}$ \\
\hline 3 & $\begin{array}{l}\text { IF Suhu Meningkat THEN akan Menurun dalam } 7 \text { tahun sebesar } 14,5 \\
\text { sdampai dengan } 15,5^{\circ} \mathrm{C}\end{array}$ & $\begin{array}{l}=\frac{6}{12} \times 100 \% \\
=50 \%\end{array}$ \\
\hline 4 & $\begin{array}{l}\text { IF Suhu Menurun THEN akan Menurun dalam } 6 \text { sampai dengan } 7 \text { tahun } \\
\text { sebesar } 14,4 \text { sdampai dengan } 15,5^{\circ} \mathrm{C}\end{array}$ & $\begin{array}{l}=\frac{5}{12} \times 100 \% \\
=33 \%\end{array}$ \\
\hline
\end{tabular}




\begin{tabular}{|c|c|c|}
\hline No & Rule & Confidence \\
\hline 5 & $\begin{array}{l}\text { IF Suhu Meningkat THEN akan Menurun dalam } 6 \text { tahun sebesar 14,5 } \\
\text { sdampai dengan } 15,2^{\circ} \mathrm{C}\end{array}$ & $\begin{array}{l}=\frac{3}{12} \times 100 \% \\
=25 \%\end{array}$ \\
\hline 6 & $\begin{array}{l}\text { IF Suhu Menurun THEN akan Meningkat dalam } 6 \text { tahun sebesar 14,5 } \\
\text { sdampai dengan } 16,4^{\circ} \mathrm{C}\end{array}$ & $\begin{array}{l}=\frac{3}{15} \times 100 \% \\
=20 \%\end{array}$ \\
\hline 7 & $\begin{array}{l}\text { IF Suhu Menurun THEN akan Meningkat dalam } 7 \text { tahun sebesar } 14,5 \\
\text { sdampai dengan } 15,5^{\circ} \mathrm{C}\end{array}$ & $\begin{array}{l}=\frac{2}{15} \times 100 \% \\
=20 \%\end{array}$ \\
\hline
\end{tabular}

Untuk mendapatkan aturan yang mendekati data asli, maka berusaha memangkas aturan dengan menentukan tingkat keyakinan untuk masing-masing aturan yang diperoleh. 7 Aturan diatas merupakan hasil penggabungan interval tahun seiring dengan perubahan pola yang ditemukan dari aturan semula yakni 28 aturan. 7 aturan diurutkan berdasarkan tingkat keyakinan atau confidence masing-masing rule. Dengan penemuan aturan yang telah diperoleh sebesar 7 aturan dan tingkat keyakinan/confidence yang berbeda-beda. Untuk penemuan pengetahuan yang lebih maksimal dilakukan perengkingan aturan dengan menggunakan pengukuran J yakni

Tabel 4. Hasil perengkingan aturan dengan J-Measure pada periode tahunan

\begin{tabular}{|c|c|c|}
\hline No & Rule & J-Measure \\
\hline 1 & $\begin{array}{l}\text { IF Suhu Meningkat THEN akan Menurun dalam } 6 \\
\text { sampai dengan } 7 \text { tahun sebesar } 14,5 \text { sdampai dengan } \\
15,5^{\circ} \mathrm{C}\end{array}$ & $\begin{array}{l}=28\left[0,32 x \log \left(\frac{0.32}{9}\right)\right. \\
\left.+(1-0.32) x \log \left(\frac{1-0.32}{1-9}\right)\right] \\
=-76,83\end{array}$ \\
\hline 2 & $\begin{array}{l}\text { IF Suhu Menurun THEN akan Meningkat dalam } 6 \\
\text { sampai dengan } 10 \text { tahun sebesar } 14,8 \text { sdampai dengan } \\
16,4^{\circ} \mathrm{C}\end{array}$ & $\begin{array}{l}=28\left[0,28 x \log \left(\frac{0.28}{8}\right)\right. \\
\left.+(1-0.28) x \log \left(\frac{1-0.28}{1-8}\right)\right] \\
=-72,13\end{array}$ \\
\hline 3 & $\begin{array}{l}\text { IF Suhu Meningkat THEN akan Menurun dalam } 7 \\
\text { tahun sebesar } 14,5 \text { sdampai dengan } 15,5^{\circ} \mathrm{C}\end{array}$ & $\begin{array}{l}=28\left[0,21 x \log \left(\frac{0.21}{6}\right)\right. \\
\left.+(1-0.21) x \log \left(\frac{1-0.21}{1-6}\right)\right] \\
=-60,52\end{array}$ \\
\hline 4 & $\begin{array}{l}\text { IF Suhu Menurun THEN akan Menurun dalam } 6 \\
\text { sampai dengan } 7 \text { tahun sebesar 14,4 sdampai dengan } \\
15,5^{\circ} \mathrm{C}\end{array}$ & $\begin{array}{l}=28\left[0,17 x \log \left(\frac{0.17}{5}\right)\right. \\
\left.+(1-0.17) x \log \left(\frac{1-0.17}{1-5}\right)\right] \\
=-52,64\end{array}$ \\
\hline 5 & $\begin{array}{l}\text { IF Suhu Meningkat THEN akan Menurun dalam } 6 \\
\text { tahun sebesar } 14,5 \text { sdampai dengan } 15,2^{\circ} \mathrm{C}\end{array}$ & $\begin{array}{l}=28\left[0,10 x \log \left(\frac{0.10}{3}\right)\right. \\
\left.+(1-0.10) x \log \left(\frac{1-0.10}{1-3}\right)\right] \\
=-29,64\end{array}$ \\
\hline
\end{tabular}




\begin{tabular}{|l|l|l|}
\hline No & Rule & J-Measure \\
\hline 6 & $\begin{array}{l}\text { IF Suhu Menurun THEN akan Meningkat dalam } 6 \\
\text { tahun sebesar 14,5 sdampai dengan 16,40 }\end{array}$ & $\begin{array}{l}=28\left[0,10 x \log \left(\frac{0.10}{3}\right)\right. \\
\left.+(1-0.10) x \log \left(\frac{1-0.10}{1-3}\right)\right] \\
=-29,64\end{array}$ \\
\hline 7 & $\begin{array}{l}\text { IF Suhu Menurun THEN akan Meningkat dalam } 7 \\
\text { tahun sebesar 14,5 sdampai dengan 15,50 }\end{array}$ & $\left.\left.\begin{array}{l}=28\left[0,10 x \log \left(\frac{0.10}{3}\right)\right. \\
1-0.10 \\
1-3\end{array}\right)\right]$ \\
\hline
\end{tabular}

Hasil perengkingan dengan pengukuran J diurutkan berdasarkan hasil terkecil. Sebagai rangkuman hasilnya dan membandingkannya dengan hasil pengukuran J setiap rule.

\section{KESIMPULAN}

Berdasarkan analisa pengetahuan dari setiap window maka dapat ditentukan rule yang berpotensial menarik serta memangkas rule yang tidak menarik, rule yang cenderung memiliki redundansi, rule yang tidak memiliki redundansi, maka best rulenya

1. IF Suhu Meningkat THEN akan Menurun dalam 6 sampai dengan 7 tahun sebesar 14,5 sdampai dengan $15,5^{\circ} \mathrm{C}$

2. IF Suhu Menurun THEN akan Meningkat dalam 6 sampai dengan 10 tahun sebesar 14,8 sdampai dengan $16,4^{\circ} \mathrm{C}$

3. IF Suhu Meningkat THEN akan Menurun dalam 7 tahun sebesar 14,5 sdampai dengan $15,5^{\circ} \mathrm{C}$

\section{DAFTAR PUSTAKA}

[1] J. Han, M. Kamber, and J. Pei, Data Mining Concepts and Techniques, Third Edit., vol. 1. Elsevier, 2012.

[2] J. Lin, S. Lonardi, J. Lin, and S. Lonardi, "Visualizing and Discovering Non-Trivial Patterns In Large Time Series Databases Short running title : Time Series Visualization Visualizing and Discovering Non-Trivial Patterns In Large Time Series Databases," 2005.

[3] S. Rodpongpun, V. Niennattrakul, and C. A. Ratanamahatana, "Selective Subsequence Time Series clustering," Knowledge-Based Syst., vol. 35, pp. 361-368, 2012.

[4] J. Serr, "Ranking and significance of variable-length similarity-based time series motifs '," 2015.

[5] A. Mueen, S. Cash, and B. Westover, "Exact Discovery of Time Series Motifs," 2002.

[6] N. Castro and P. J. Azevedo, "Time Series Motifs Statistical Significance," 2008.

[7] R. Fujimaki, S. Hirose, and T. Nakata, "Theoretical analysis of subsequence time-series clustering from a frequency-analysis viewpoint," Sdm Siam, no. Figure 1, pp. 506-517, 2008.

[8] U. Ramer, "An Iterative Procedure for the Polygonal Approximation of Planar Curves. Computer Graphics and Image Processing," pp. 244-256, 1972.

[9] M. Heckbert, P.S. and Garland, "Survey of Polygonal Surface Simplification Algorithms, Multiresolution Surface Modeling Course.," 1997.

[10] K. U. Yoshiki Tanaka, Kazuhisa Iwamoto, "Discovery of Time-Series Motif from MultiDimensional Data Based on MDL Principle," Springer Sci. + Bus. Media, Inc. Manuf. Netherlands, no. 2000, pp. 269-300, 2005. 